Article

\title{
Laboratory Operando XAS Study of Sodium Iron Titanite Cathode in the Li-Ion Half-Cell
}

\author{
Victor Shapovalov ${ }^{1, *}$, Alexander Guda ${ }^{1}\left[\mathbb{C}\right.$, Vera Butova ${ }^{1}\left(\mathbb{D}\right.$, Igor Shukaev ${ }^{2}$ and Alexander Soldatov ${ }^{1, *}$ \\ 1 The Smart Materials Research Institute, Southern Federal University, 178/24 A. Sladkova Street, \\ 344090 Rostov-on-Don, Russia; guda@sfedu.ru (A.G.); vbutova@sfedu.ru (V.B.) \\ 2 Department of Chemistry, Southern Federal University, 7 Zorge Street, 344090 Rostov-on-Don, Russia; \\ ishukaev@sfedu.ru \\ * Correspondence: viks@sfedu.ru (V.S.); soldatov@sfedu.ru (A.S.)
}

Citation: Shapovalov, V.; Guda, A.; Butova, V.; Shukaev, I.; Soldatov, A. Laboratory Operando XAS Study of Sodium Iron Titanite Cathode in the Li-Ion Half-Cell. Nanomaterials 2021, 11, 156. https://doi.org/10.3390/ nano11010156

Received: 10 December 2020

Accepted: 7 January 2021

Published: 9 January 2021

Publisher's Note: MDPI stays neutral with regard to jurisdictional clai$\mathrm{ms}$ in published maps and institutional affiliations.

Copyright: $\odot 2021$ by the authors. Licensee MDPI, Basel, Switzerland. This article is an open access article distributed under the terms and conditions of the Creative Commons Attribution (CC BY) license (https:// creativecommons.org/licenses/by/ $4.0 /)$.

\begin{abstract}
Electrochemical characterization of the novel sodium iron titanate $\mathrm{Na}_{0.9} \mathrm{Fe}_{0.45} \mathrm{Ti}_{1.55} \mathrm{O}_{4}$ was performed upon cycling in the Li-ion half-cell. The material exhibited stable cycling in the voltage range $2-4.5 \mathrm{~V}$, and the number of alkali ions extracted per formula unit was approximately half of the Na stoichiometry value. Using laboratory $X$-ray absorption spectrometry, we measured operando Fe K-edge X-ray absorption spectra in the first 10 charge-discharge cycles and quantified the portion of charge associated with the transition metal redox reaction. Although $3 \mathrm{~d}$ metals are commonly accepted redox-active centers in the intercalation process, we found that in all cycles the amount of oxidized and reduced Fe ions was almost $20 \%$ less than the total number of transferred electrons. Using density functional theory (DFT) simulations, we show that part of the reversible capacity is related to the redox reaction on oxygen ions.
\end{abstract}

Keywords: Na-ion; cathode material; sodium iron titanate; operando study; X-ray absorption spectroscopy; DFT calculations

\section{Introduction}

The trend in modern energetics toward increasing the use of renewable power sources heavily depends on the development of efficient energy storage and conversion systems [1-3]. In this scope, Na-ion batteries have drawn increased attention for their applications in large-scale energy storage facilities [4]. Much effort has been invested in the development of hybrid Li/Na-ion systems based on polycationic electrode materials or the use of Li-based (Na-based) electrode or electrolyte in Na-based (Li-based) electrochemical systems. Such combinations may benefit from both types of alkali metal chemistries and compensate for their primary drawbacks [5]. As an example, the electrochemical performance of overlithiated oxide cathode materials may be drastically improved by concentration-difference-driven molten salt $\mathrm{Li} / \mathrm{Na}$ ion exchange [6]. Another promising class of materials is Na-rich rocksalt oxides, $\mathrm{Na}_{1+\mathrm{x}} \mathrm{M}_{1-\mathrm{x}} \mathrm{O}_{2}(\mathrm{M}=$ transition metal), combining cationic and anionic redox activity. Their synthesis remains challenging, and mixed compounds such as $\mathrm{Na}\left(\mathrm{A}_{\mathrm{x}} \mathrm{M}_{1-\mathrm{x}}\right) \mathrm{O}_{2}(\mathrm{~A}=\mathrm{Li}, \mathrm{Mg}$, or $\mathrm{Zn})$ may become an alternative. However, it is challenging to achieve the stability of such materials in both $\mathrm{Li}$ and $\mathrm{Na}$ systems [7]. Another step toward dual-ion systems with improved performance may be the employment of materials with mixed d-metal cations or materials that exhibit anion redox reactions such as oxygen redox. In this scope, Ti-doped polyanionic or Na superionic conductor (NASICON) type electrodes, as well as pure titanate-based cathodes, have become a hot topic [8]. Carbon coating increases the capacity and improves the high-rate stability of $\mathrm{LiTi}_{2}\left(\mathrm{PO}_{4}\right)_{3}$ in aprotic Na cells [9]. Density functional theory (DFT) calculations show that the electrochemical ion exchange of Li ions by Na during cycling occurs through a two-phase reaction. 
The processes in electrochemical systems are complex and require a deep understanding of the chemical composition as well as atomic and electronic structure of electrode materials, and the dynamics of their change during battery operation $[10,11]$. Operando techniques provide the most reliable and authentic insight into the internal electrochemical reactions of the cell, including transient processes and short-living intermediate species [12-14]. Recently there were several works published on the study of advanced polyanionic, Narich, and NASICON-type electrode materials for Na-ion batteries [15,16]. Broux et al. reported the $\mathrm{V}$ disproportionation upon sodium extraction confirmed for $\mathrm{Na}_{3} \mathrm{~V}_{2}\left(\mathrm{PO}_{4}\right)_{2} \mathrm{~F}_{3}$ polyanionic cathode utilizing operando X-ray absorption spectroscopy (XAS) [17]. Principal component analysis (PCA) of V K-edge X-ray absorption near-edge structure (XANES) data enabled the extraction of three components, corresponding to the initial $\mathrm{V}^{\mathrm{III}}-\mathrm{V}^{\mathrm{III}}$, intermediate $\mathrm{V}^{\mathrm{III}}-\mathrm{V}^{\mathrm{IV}}$, and final $\mathrm{V}^{\mathrm{III}}-\mathrm{V}^{\mathrm{V}}$ phases. NASICON-type $\mathrm{Na}_{3} \mathrm{VCr}\left(\mathrm{PO}_{4}\right)_{3}$ was investigated by in situ synchrotron X-ray diffraction (XRD) and ex situ XAS and nuclear magnetic resonance (NMR) spectroscopy [18], which revealed $\mathrm{V}^{3+} / \mathrm{V}^{4+}$ and $\mathrm{V}^{4+} / \mathrm{V}^{5+}$ redox couples, and the mechanism of the capacity decay was explained by the structural irreversibility with the formation of a metastable phase [19]. A combination of in situ XRD, operando transmission X-ray microscopy, and XANES (TXM-XANES) was used to unravel the origin of irreversible capacity loss in sodium metal-oxides [20]. It was reported that at the singleparticle level, the electrochemically active phase transformation exhibits a dissymmetric spatial distribution with a "core-shell" reaction mechanism, which exhibits a different discharge behavior due to the existence of the irreversible phase $\left(\mathrm{Na}_{0.17} \mathrm{NiO}_{2}\right)$. Combined experimental and theoretical investigation of a novel NASICON-type $\mathrm{Na}_{3.5} \mathrm{Mn}_{0.5} \mathrm{~V}_{1.5}\left(\mathrm{PO}_{4}\right)_{3}$ cathode was reported by Zhang et al [21]. In situ XRD revealed that the electrochemical process exhibited highly reversible biphasic transition. The $\mathrm{Mn}^{2+} / \mathrm{Mn}^{3+}$ and $\mathrm{V}^{3+} / \mathrm{V}^{4+}$ redox couples occurring during the $\mathrm{Na}^{+}$extraction/insertion were further verified by ex situ XANES and X-ray photoelectron spectroscopy (XPS) spectra. DFT computations revealed that the intrinsic low $\mathrm{Na}^{+}$migration energy barrier was responsible for the superb rate capability of this material. Ti-doped NASICON-Na ${ }_{3} \mathrm{VTi}\left(\mathrm{PO}_{4}\right)_{3}$ cathodes were investigated by means of in situ synchrotron XRD and XAS to unravel the underlying sodium storage mechanism and charge compensation behavior [22]. Analysis of $\mathrm{V}$ and $\mathrm{Ti}$ charge states addressed by XANES showed that initial charge may be attributed to $\mathrm{V}^{3+} / \mathrm{V}^{4+}$ oxidation, while $\mathrm{Ti}^{3+} / \mathrm{Ti}^{4+}$ reduction occurs on discharge.

Operando research of battery materials usually implies the use of synchrotron radiation due to its high flux, allowing better time and spatial resolution, and the ability to maintain a proper sample environment for moisture- and oxygen-sensitive materials through the use of special electrochemical cells or chambers. However, the use of carefully tuned equipment and compatible, thoroughly designed, X-ray-transparent electrochemical cell allows one to perform operando experiments using only laboratory equipment. Recently, laboratory XAS and Mössbauer spectroscopy were applied in an operando regime to address the details of redox processes in a series of Li-ion cathodes based on $\mathrm{LiFe}_{0.5} \mathrm{Mn}_{0.5} \mathrm{PO}_{4}$ mixed d-metal olivines [23]. In the present work, we studied a novel $\mathrm{Na}$-ion cathode material based on $\mathrm{Na}_{x} \mathrm{Fe}_{\frac{x}{2}} \mathrm{Ti}_{2-\frac{x}{2}} \mathrm{O}_{4}$ sodium iron titanate and its electrochemical performance in a Li-ion half-cell. Preliminary results of electrochemical cycling suggest that samples with $\mathrm{x}=0.9$ show promising electrochemical performance, including high stability for demanding systems such as dual Li/Na-ion batteries. The local atomic and electronic structure of this material was investigated by means of laboratory X-ray absorption spectroscopy in an operando regime during charge and discharge. Theoretical ab initio DFT calculations were applied to investigate the peculiarities of redox processes in the dual-ion system.

\section{Materials and Methods}

The synthesis was performed according to the protocol described in [24]. Starting materials included $\mathrm{FeTiO}_{3}$, sodium carbonate $\left(\mathrm{Na}_{2} \mathrm{CO}_{3}\right)$, and rutile $\left(\mathrm{TiO}_{2}\right) . \mathrm{TiO}_{2}$ and $\mathrm{Na}_{2} \mathrm{CO}_{3}$ were calcinated for purifying. In the first stage, we obtained an intermediate 
compound- $\mathrm{Na}_{8} \mathrm{Ti}_{5} \mathrm{O}_{14}$ - using sodium carbonate and $\mathrm{TiO}_{2}$ in the solid-state reaction [24]. In the second stage, fine powders of $\mathrm{FeTiO}_{3}, \mathrm{TiO}_{2}$, and $\mathrm{Na}_{8} \mathrm{Ti}_{5} \mathrm{O}_{14}$ were mixed in the molar ratio 4:4.78:1, and ground and pressed into a pellet. The pellet was heated at $1050{ }^{\circ} \mathrm{C}$ in a tube oven in argon flow for $6 \mathrm{~h}$. After synthesis, the sample was rapidly cooled to prevent possible phase changes. To obtain a fully oxidized phase, the sample of $\mathrm{Na}_{0.9} \mathrm{Fe}_{0.45} \mathrm{Ti}_{1.55} \mathrm{O}_{4}$ was calcined for $5 \mathrm{~h}$ in air at $1000{ }^{\circ} \mathrm{C}$. After this treatment, the color was changed from black to brown. It was designated as $\mathrm{Ox}-\mathrm{Na}_{0.9} \mathrm{Fe}_{0.45} \mathrm{Ti}_{1.55} \mathrm{O}_{4}$.

Powder X-ray diffraction (XRD) profiles were recorded on a D2 Phaser laboratory $X$-ray diffractometer (Bruker Corporation, Billerica, MA, USA) in the $2 \theta$ range from $10^{\circ}$ to $60^{\circ}$ using $\mathrm{Cu} \mathrm{K} \alpha$ radiation $\left(1.54056 \AA\right.$ ) with a step of $0.01^{\circ}$. Profile analysis was performed using the Jana2006 program (Laboratory of Crystallography, Institute of Physics, Prague, Czech Republic) [25].

X-ray absorption near edge structure (XANES) spectra were measured in operando conditions with the R-XAS Looper (Rigaku, Tokyo, Japan) laboratory X-ray absorption spectrometer at the Smart Materials Research Institute of Southern Federal University. All measurements were performed in transmission geometry with Ge (311) crystal as a monochromator, providing energy resolution $\Delta \mathrm{E}=1.4 \mathrm{eV}$ for the Fe K-edge. The incident beam intensity was measured by Ar-filled (300 mbar) ionization chamber, and the transmitted intensity by a scintillation counter with a photomultiplier tube. Acquired spectra were normalized and flattened using the Athena tool from the Demeter package [26]. No energy correction or averaging of operando data were performed. Spectra for reference compounds were measured in 4 scans with subsequent averaging, normalization, and flattening. PCA of operando data was performed using PyFitIt software (v. 2.0.7, The Smart Materials Research Institute, Southern Federal University, Rostov-on-Don, Russia) [27,28].

A home-built electrochemical cell [23] was used to enable operando XAS measurements in a transmission geometry (Figure 1). The cell is equipped with a set of large glassy carbon (GC) windows to allow X-rays to pass through the sample inside the cell. The cathode material is placed on one of the windows, which acts as a current collector. The cathode sample and anode foil are separated by Whatman grade 70 glass fiber filter and pressed together using a spring-loaded copper anode current collector, thus providing optimal electrochemical performance for a varying amount of cathode material. The cell's design allows for adjustment of the volume of cathode sample to achieve an optimal value of the total sample absorption, absorbance edge step, and signal-to-noise ratio.
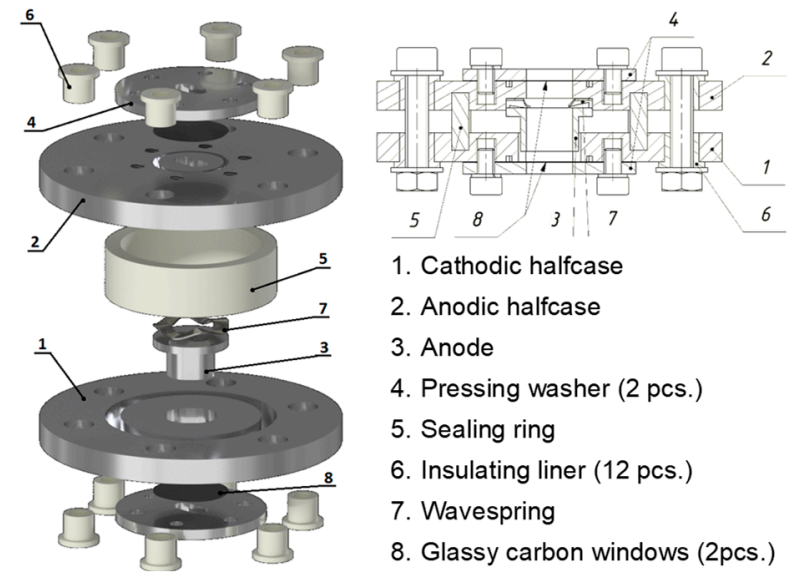

(a)

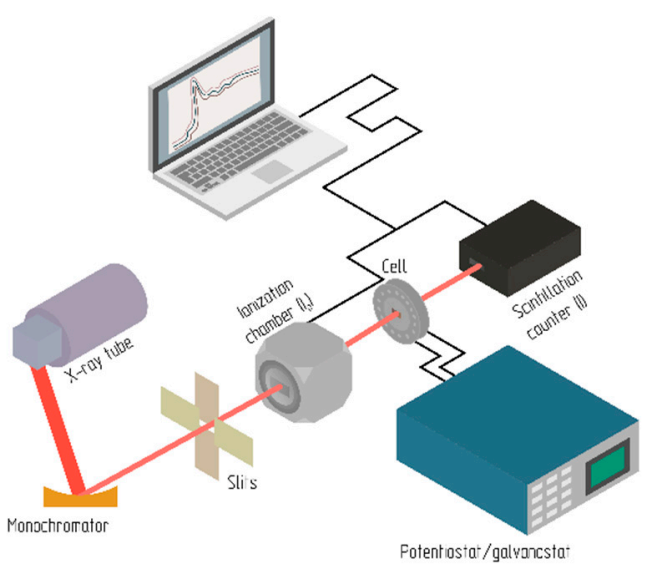

(b)

Figure 1. (a) Design of the electrochemical cell for laboratory operando XAS studies. (b) Scheme of the experimental setup. The main parts of the laboratory X-ray absorption spectrometer are shown, the cell is installed on the sample position and connected to a potentiostat/galvanostat device. 
Sample powder was mixed and mortared with $20 \mathrm{wt} \%$ of carbon (Timcal Super P Conductive, Alpha Aesar) and placed as a cathode into the electrochemical cell with a load of $13.7 \mathrm{mg} / \mathrm{cm}^{2}$ (calculated for optimal total absorption and edge-step using XAFSmass software (v. 1.4.0, Konstantin Klementiev, MAX IV Laboratory, Lund, Sweden) [29]. Li foil was used as an anode and $1 \mathrm{M} \mathrm{LiPF}_{6}$ in 1:1 EC:DMC commercial solution (Sigma) was used as an electrolyte. The cell was cycled in the 1.6 to $4.5 \mathrm{~V}$ range with a current of $\mathrm{C} / 20 \mathrm{~mA}$ (where $\mathrm{C}$ is the theoretical cell capacity).

$\mathrm{Ab}$ initio DFT calculations were performed using the VASP package (v. 5.4, VASP Software GmbH, Vienna, Austria) [30,31] with a set of GGA-PBE projector-augmentedwave pseudopotentials with spin polarization. GGA + U correction was added according to the Dudarev approach with (U-J) $=7 \mathrm{eV}$ for both Fe and Ti atoms. For each stoichiometry of alkali metal, a two-step geometry optimization was performed, including cell volume and then atomic positions. The conjugate gradient algorithm was used for ionic relaxation and a special Davidson block iteration scheme for electronic minimization. Optimized structures were further used for accurate single-point calculations of total energy, charge densities, and atomic charges according to the Bader method [32,33]. The same calculation steps were repeated to obtain Bader charge values from various reference compounds with known Fe and Ti oxidation states.

\section{Results and Discussion}

The crystal structure of the $\mathrm{Na}_{0.9} \mathrm{Fe}_{0.45} \mathrm{Ti}_{1.55} \mathrm{O}_{4}$ sample is attributed to non-stochiometric iron titanate (Figure 2). All peaks on the XRD pattern could be assigned to orthorhombic symmetry, space group Pnma (no. 62). The crystal lattice of the material is characterized by wide channels along the $b$ axis, favorable for alkali metal cation intercalation (Figure 2a). A phase transition occurs after calcination in air. The obtained phase $\mathrm{Ox}-\mathrm{Na}_{0.9} \mathrm{Fe}_{0.45} \mathrm{Ti}_{1.55} \mathrm{O}_{4}$ exhibited a freudenbergite structure type with monoclinic symmetry, space group C12/m1 (no. 12).

Figure 3 shows the Fe K-edge X-ray absorption spectra obtained during the first 10 cycles, where red and blue curves mark the spectra measured for lowest and highest potential, respectively. Each spectrum acquisition took around $25 \mathrm{~min}$. However, in the analysis, we use only part of this energy region, which required ca. 12 min for measuring. Assuming a slow cycling rate, the cell state can be considered stable during single XANES measurement. Prominent changes related to the redox processes can be clearly observed. The chemical shift of the edge position indicates the change in the oxidation state of Fe. The shift of the second absorption maximum around $7170 \mathrm{eV}$ to the higher energies upon charge suggests decreasing interatomic distances. While laboratory X-ray diagnostics lacks a good signal-to-noise ratio in the spectra in comparison to synchrotron data, the tool offers an almost unlimited time range for data acquisition.

In total, 200 spectra were collected during 10 consecutive cycles over $85 \mathrm{~h}$. Since the XAS spectrum of a multiphase bulk compound is a mere superposition of XAS spectra for each phase, one can use principal component analysis (PCA) to mathematically decompose a series of spectra to extract the pure spectra of involved phases. In this case, we used PCA to extract the spectra of pure phases forming in the electrochemical process and corresponding concentrations. All spectra were interpolated to a single energy range. In the first step, singular value decomposition was applied to extract a given number of abstract components from the series of spectra. Two abstract spectra in our case were further converted to chemically relevant information using target transformation. The following physical constraints were assumed: spectra should be normalized, the values of concentrations should be positive, and at least one of the components under consideration should represent either the fully reduced or fully oxidized phase of the material. In this way, 2 components were successfully identified, as shown in Figure 4. 


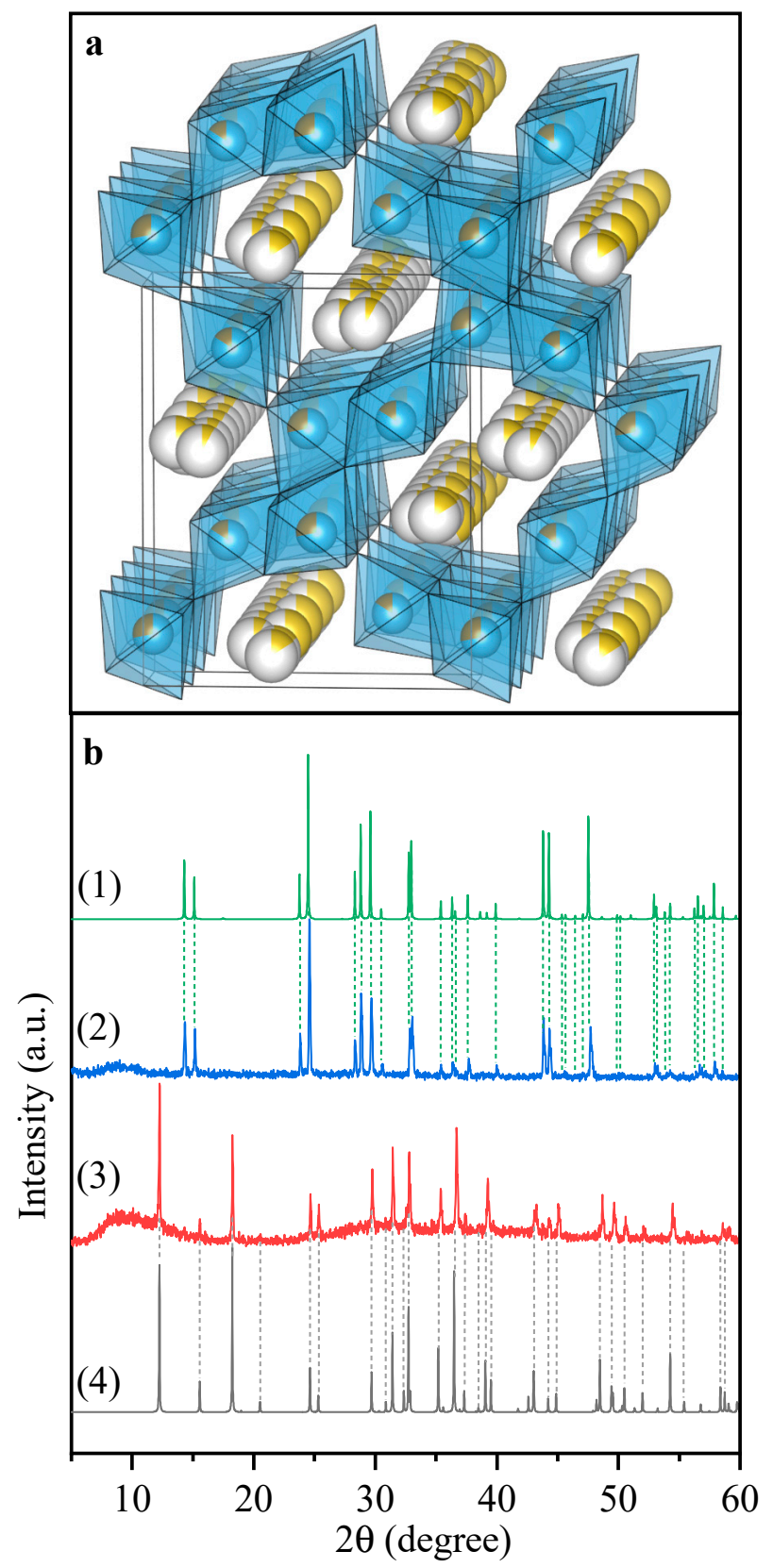

Figure 2. (a) Structure of $\mathrm{Na}_{0.9} \mathrm{Fe}_{0.45} \mathrm{Ti}_{1.55} \mathrm{O}_{4}$ refined from $\mathrm{XRD}$, exhibiting wide intercalation channels along the $b$ axis. (b) XRD powder profiles of as-prepared $\mathrm{Na}_{0.9} \mathrm{Fe}_{0.45} \mathrm{Ti}_{1.55} \mathrm{O}_{4}$ sample (3) and the same sample after calcination in air, $\mathrm{Ox}-\mathrm{Na}_{0.9} \mathrm{Fe}_{0.45} \mathrm{Ti}_{1.55} \mathrm{O}_{4}$ (2). Powder diffraction profiles of nonstoichiometric iron titanate (4) and freudenbergite (1) structure types were calculated according to crystallographic data from Crystallography Open Database cards No. 00-100-1512 and 00-901-1187, respectively. 


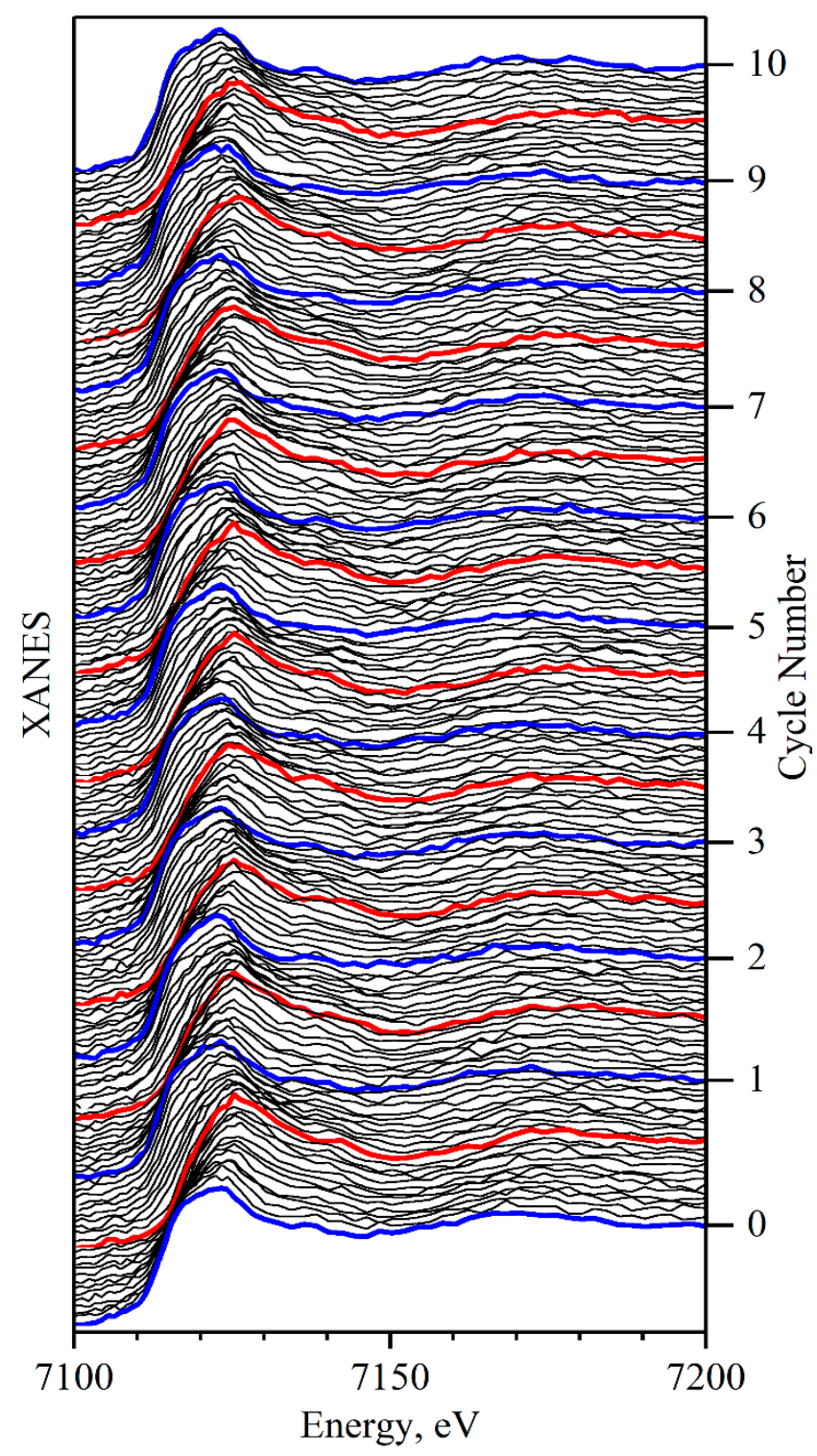

Figure 3. Operando Fe K-XANES spectra for $\mathrm{Na}_{x} \mathrm{Fe}_{\frac{x}{2}} \mathrm{Ti}_{2-\frac{x}{2}} \mathrm{O}_{4}$ sample $(x=0.9)$ during first 10 cycles. Blue and red curves correspond to fully discharged and charged states of the cell, respectively.

Figure 4 shows the spectra of the pure phases extracted from PCA compared to the experimental reference spectra of $\mathrm{Fe}^{2+}$ and $\mathrm{Fe}^{3+}$ compounds. The component corresponding to an $\mathrm{Fe}^{2+}$ phase shows good agreement with the $\mathrm{FeTiO}_{3}$ reference in terms of absorption edge position and overall profile of the spectrum. The second component can be ascribed to an $\mathrm{Fe}^{3+}$ reference compound represented by $\mathrm{Ox}-\mathrm{Na}_{0.9} \mathrm{Fe}_{0.45} \mathrm{Ti}_{1.55} \mathrm{O}_{4}$, which is basically fully oxidized $\mathrm{Na}_{0.9} \mathrm{Fe}_{0.45} \mathrm{Ti}_{1.55} \mathrm{O}_{4}$ sample. Thus, the spectrum of the second component corresponds to electrochemically oxidized $\mathrm{Fe}^{3+}$ ions.

The top panel of Figure 4 shows the concentrations of phases corresponding to $\mathrm{Fe}^{2+}$ and $\mathrm{Fe}^{3+}$ components as a function of time compared to the cell voltage during the first 10 cycles. The material exhibits a single steep plateau on both charge and discharge, while the Fe oxidation state evenly changes across the whole voltage range. The $\mathrm{Fe}^{2+} / \mathrm{Fe}^{3+}$ conversion rate slowly decreases during the first 3 cycles and then stabilizes. This result is consistent with the behavior observed in electrochemistry, where specific capacity on the discharge drops from $70 \mathrm{mAh}$ in the first cycle to an average value of $55 \mathrm{mAh}$ during the fourth and consecutive cycles (Figure S3 in SI). Such behavior may be attributed to the partial collapse of the cathode material structure (intercalation channels, in particular) 
upon substitution of $\mathrm{Na}$ ions to the $\mathrm{Li}$ ions since $\mathrm{Na}_{0.9} \mathrm{Fe}_{0.45} \mathrm{Ti}_{1.55} \mathrm{O}_{4}$ was cycled vs. $\mathrm{Li}$ with Li-ionic electrolyte.
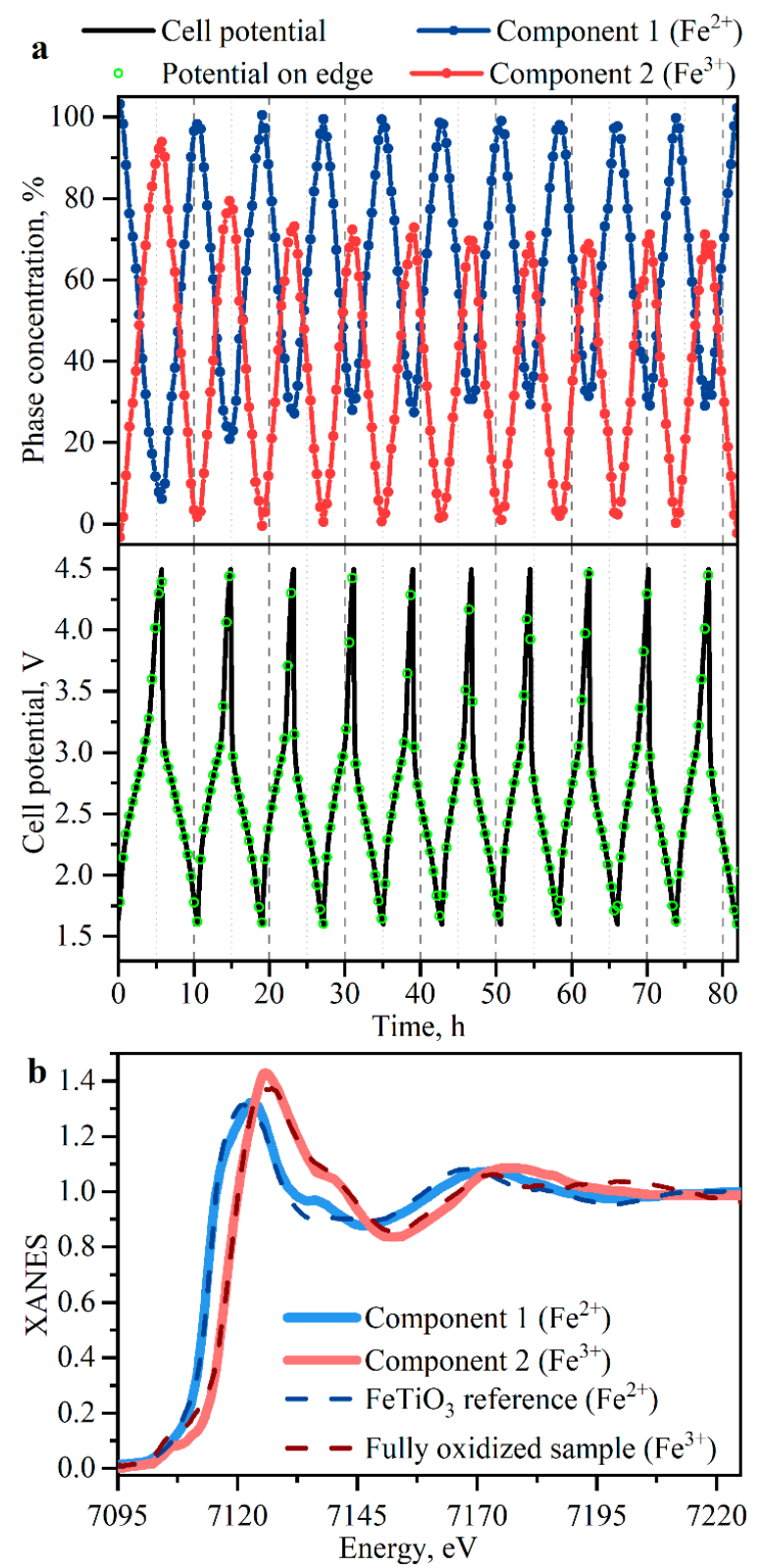

Figure 4. (a) Concentrations of the principal components extracted upon PCA of the first 10 cycles and the cell potential plotted on the same time scale. Green circles correspond to the Fe K-edge position in each individual XANES spectrum; (b) Spectra of the principal components after target transformation, compared to the experimental spectra of $\mathrm{Fe}^{2+}$ and $\mathrm{Fe}^{3+}$ reference compounds.

In Figure 5, we quantitatively compare the number of electrons transferred through the cell during discharge with the number of $\mathrm{Fe}^{2+} / \mathrm{Fe}^{3+}$ transitions (both values are per formula unit). Despite sharing the same trend, the number of electrons is $20 \%$ higher than the number of redox-active Fe ions in every cycle. This means that $20 \%$ of the reversible capacity arises from the electrons participating in another reversible redox reaction, which is different from $\mathrm{Fe}^{2+} / \mathrm{Fe}^{3+}$ transition. The reversible capacity of $\mathrm{Li}$ - and $\mathrm{Na}$-ion batteries often is not limited to d-metal cation redox alone, but a notable part of it may be contributed by anion (usually oxygen) [34]. Reversible oxygen redox was reported previously for structures with $4 \mathrm{~d}$ and $5 \mathrm{~d}$ elements, such as $\mathrm{Li}_{3} \mathrm{IrO}_{4}$ Li-rich layered rocksalt [35]. However, in high-energy lithium- and manganese-rich (LMR) layered materials, a similar effect 
may induce a severe capacity loss relative to the initial cycle. The observed reversibility of oxygen redox phenomena is limited to a certain cut-off potential. Beyond this point, $\mathrm{O}_{2}$ release from the structure may occur, accompanied by continuous reduction of transition metal cation, activating lower-voltage redox couples and causing microstructural defects [36]. This behavior was reported for $\mathrm{Li}_{4} \mathrm{FeSbO}_{6}$ lithium-rich layered oxide. Unusual Fe oxidation from +3 to +4 , and limited reversibility of the oxygenated species, was directly demonstrated during the charge up to $4.2 \mathrm{~V}$, while an oxygen release process occurred upon further charge to $5.0 \mathrm{~V}$ [37].

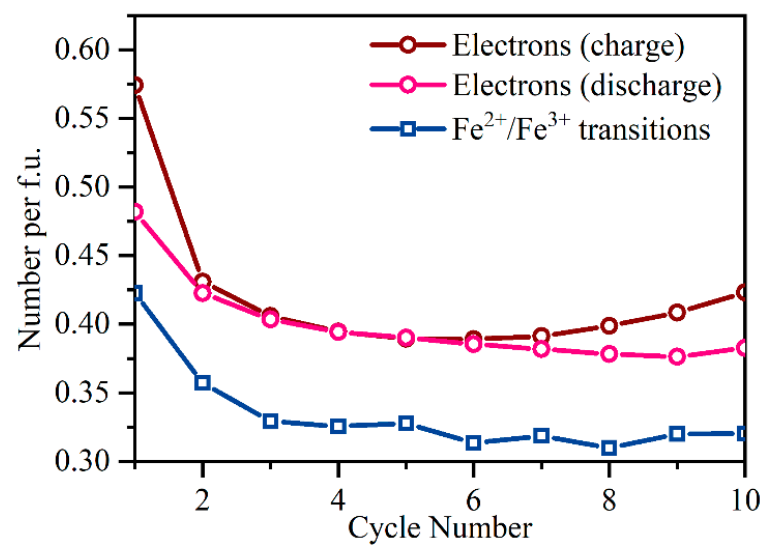

Figure 5. The number of electrons per formula unit transferred through the cell upon charge and discharge as derived from experimental electrochemistry data. The blue bottom curve shows the number of $\mathrm{Fe}^{2+} / \mathrm{Fe}^{3+}$ redox transitions per formula unit obtained from operando XAS as a function of cycle number.

To address the origin of additional capacity and validate the possibility of oxygen redox in $\mathrm{Na}_{0.9} \mathrm{Fe}_{0.45} \mathrm{Ti}_{1.55} \mathrm{O}_{4}$, a series of ab initio DFT calculations were performed. The voltage range applied for operando cycling covered the sodium stoichiometry range between $x=0.55$ and $x=0.9$. The geometry optimization and Bader charges were computed for $\mathrm{Li}_{\mathrm{x}} \mathrm{Fe}_{0.45} \mathrm{Ti}_{1.55} \mathrm{O}_{4}$ and $\mathrm{Na}_{\mathrm{x}} \mathrm{Fe}_{0.45} \mathrm{Ti}_{1.55} \mathrm{O}_{4}$ in a full range of alkali metals stoichiometry implying $x=0,0.25,0.5,0.75$, and 1 compositions. Figure 6 shows the average Bader charge for each type of atom in the cell. Bader charges are topological quantities that cannot be directly compared to the formal oxidation states of elements. Therefore, Table 1 shows Bader charges calculated for reference compounds with a known oxidation state. This comparison makes it possible to assign formal topological charges to the chemically relevant oxidation states. For both $\mathrm{Na}$ and Li alkali metals in the lattice, we observed the oxygen redox activity apart from $\mathrm{Fe}^{2+} / \mathrm{Fe}^{3+}$ redox, while Ti atoms did not participate in the redox reaction upon $\mathrm{Li}$ cycling. The calculations predict a notable difference in $\mathrm{Fe}$ oxidation state for the fully discharged $\mathrm{Li}$ and $\mathrm{Na}$ compounds (the last point for $\mathrm{x}=1$ in panel a). In the stoichiometric sample $\mathrm{Na}_{0.9} \mathrm{Fe}_{0.45} \mathrm{Ti}_{1.55} \mathrm{O}_{4}$, the iron oxidation state was $\mathrm{Fe}^{2+\delta}$ due to partial reduction of Ti atoms. However, $\mathrm{Li}_{0.9} \mathrm{Fe}_{0.45} \mathrm{Ti}_{1.55} \mathrm{O}_{4}$ contains iron in an $\mathrm{Fe}^{2+}$ charge state. This effect is confirmed by the Fe K-edge XANES (see Figure S4 in SI). The energy position of the absorption edge for the as-prepared sample $\left(\mathrm{Na}_{0.9} \mathrm{Fe}_{0.45} \mathrm{Ti}_{1.55} \mathrm{O}_{4}\right)$ is shifted with respect to the fully discharged sample at subsequent cycles $\left(\mathrm{Li}_{0.9} \mathrm{Fe}_{0.45} \mathrm{Ti}_{1.55} \mathrm{O}_{4}\right.$ stoichiometry). Figure 6 shows that for higher cell potential when $\mathrm{Na} / \mathrm{Li}$ stoichiometry is below 0.45 , the oxygen atoms alone compensate the charge neutrality in the cell. However, this process is unfavorable for the high-voltage region, where molecular oxygen can be released.

To the best of our knowledge, only one compound with pure $\mathrm{Fe}^{2+}$ content in a $\mathrm{Na}_{2} \mathrm{O}-$ " $\mathrm{FeO}^{\prime}-\mathrm{TiO}_{2}$ system has previously been reported. [38]. The good properties of the studied $\mathrm{Na}_{0.9} \mathrm{Fe}_{0.45} \mathrm{Ti}_{1.55} \mathrm{O}_{4}$ material in Li cycling make this material also promising for Na-ion batteries. One of the advantages of $\mathrm{Fe}^{2+}$ with respect to $\mathrm{Fe}^{3+}$ analogs is lower $\mathrm{Fe}^{2+} / \mathrm{Fe}^{3+}$ redox potential compared to $\mathrm{Fe}^{3+} / \mathrm{Fe}^{4+}(-0.77 \mathrm{~V}$ vs. 3.4 V) [39]. The higher voltage could 
damage both electrolyte and electrode, dramatically reducing cycling stability. The number of $\mathrm{Na}+$ ions, which could be safely extracted without phase transition or collapse of the structure in the case of the $\mathrm{Fe}^{2+}$ compound, is also higher than for $\mathrm{Fe}^{3+}$ analogs.

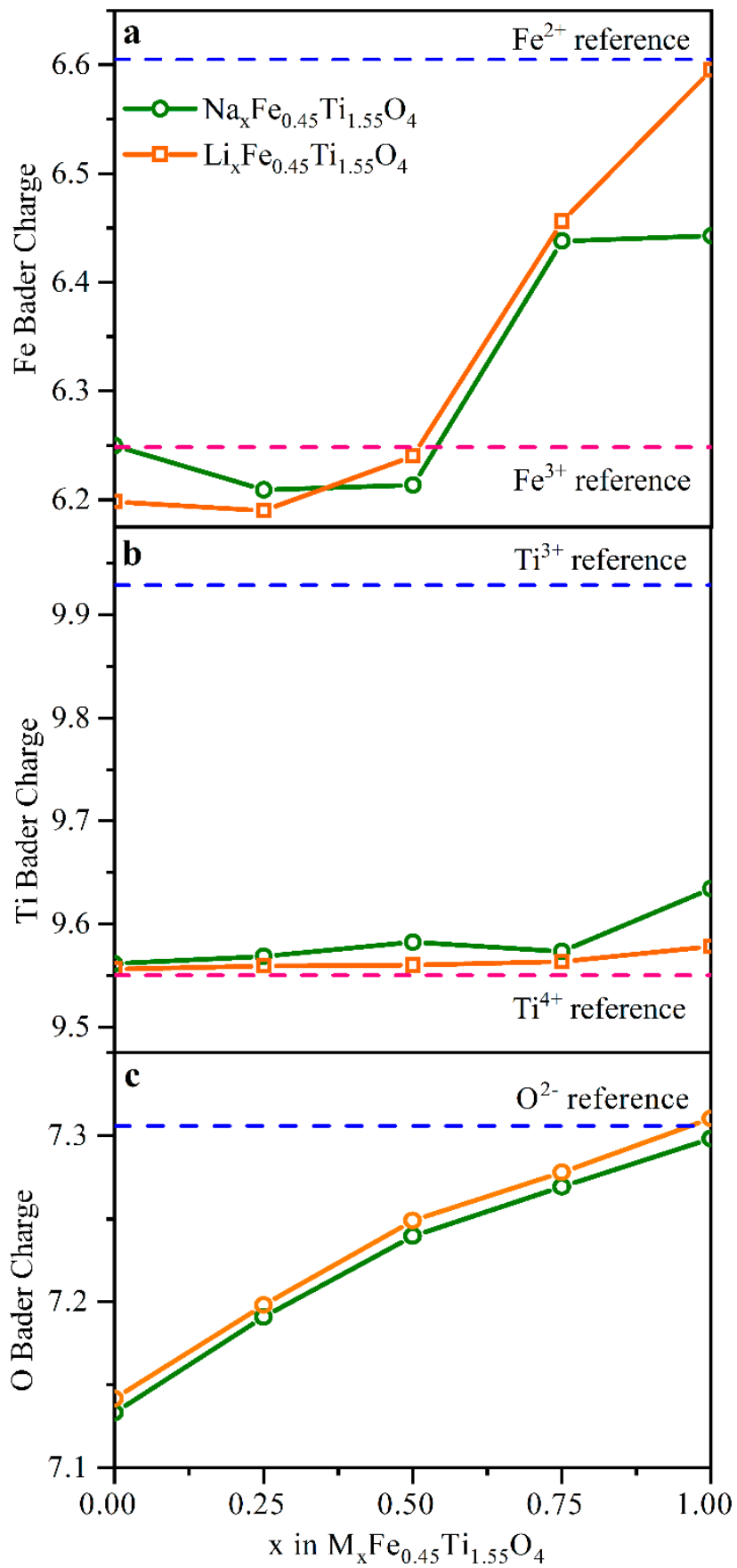

Figure 6. Bader charge analysis for the two sets of $\mathrm{M}_{\mathrm{x}} \mathrm{Fe}_{0.45} \mathrm{Ti}_{1.55} \mathrm{O}_{4}(\mathrm{x}=0,0.25,0.5,0.75$ and 1) compositions with $\mathrm{Li}$ and $\mathrm{Na}$ as $\mathrm{M}$. The values for each atom, namely Fe, Ti and $\mathrm{O}$ (panels $\mathbf{a}, \mathbf{b}$ and c, respectively), were averaged over non-equivalent atomic positions. Reference charge values (dashed lines) were obtained from calculations for reference compounds with different Fe and $\mathrm{Ti}$ oxidation states. 
Table 1. Averaged DFT Bader charge values for $\mathrm{M}_{\mathrm{x}} \mathrm{Fe}_{0.45} \mathrm{Ti}_{1.55} \mathrm{O}_{4}$ (where $\mathrm{M}=\mathrm{Li}$, Na) and reference compounds with known oxidation state $\left(\mathrm{NaFeO}_{2}, \mathrm{FeTiO}_{3}, \mathrm{Ti}_{2} \mathrm{O}_{3}\right)$.

\begin{tabular}{|c|c|c|c|c|c|c|c|c|c|c|c|c|c|}
\hline \multirow{2}{*}{ Species } & \multirow[b]{2}{*}{$X$} & \multicolumn{5}{|c|}{$\mathrm{Na}_{\mathbf{x}} \mathrm{Fe}_{0.45} \mathrm{Ti}_{1.55} \mathrm{O}_{4}$} & \multicolumn{5}{|c|}{$\mathrm{Li}_{\mathrm{x}} \mathrm{Fe}_{0.45} \mathrm{Ti}_{1.55} \mathrm{O}_{4}$} & \multirow{2}{*}{\multicolumn{2}{|c|}{$\begin{array}{c}\text { Reference } \\
\text { Values }\end{array}$}} \\
\hline & & $\mathbf{0}$ & 0.25 & 0.5 & 0.75 & 1 & 0 & 0.25 & 0.5 & 0.75 & 1 & & \\
\hline $\mathrm{Ti}$ & & 9.56 & 9.57 & 9.58 & 9.57 & 9.63 & 9.56 & 9.56 & 9.56 & 9.56 & 9.59 & $\mathrm{Ti}^{3+}$ & 9.93 \\
\hline $\mathrm{Fe}$ & & 6.25 & 6.21 & 6.21 & 6.44 & 6.44 & 6.20 & 6.19 & 6.24 & 6.46 & 6.60 & $\mathrm{Ti}^{4+}$ & 9.55 \\
\hline $\mathrm{O}$ & & 7.13 & 7.19 & 7.24 & 7.27 & 7.29 & 7.14 & 7.20 & 7.25 & 7.28 & 7.31 & $\mathrm{Fe}^{2+}$ & 6.61 \\
\hline & & & & & & & & & & & & $\mathrm{Fe}^{3+}$ & 6.25 \\
\hline & & & & & & & & & & & & $\mathrm{O}^{2-}$ & 7.31 \\
\hline
\end{tabular}

The cycling behavior of the material was assessed via X-ray absorption spectroscopy. While synchrotron facilities provide the best capabilities in terms of data quality and time resolution, they cannot support the existing huge demand for XAS studies, and much of the routine work does not require an extremely high photon flux. Hence, the development of advanced laboratory tools, including both operando cells and X-ray spectrometers, is complementary to the mega-scale research facilities [40]. The rapid development of X-ray focusing optics and detection systems opens perspectives for new designs of efficient laboratory XAS tools $[41,42]$. On the other hand, mathematical tools such as principal component analysis improve the quality of quantitative analysis, even for noisy data.

However, the soft $\mathrm{X}$-ray energy region represents a challenge for operando studies, even at synchrotron radiation sources [43-45]. Therefore, the use of DFT theoretical approaches is a powerful addition to laboratory experimental studies [46]. We were not able to address the electrochemical behavior of $\mathrm{O}$ and Ti atoms in the material using the current experimental setup; however, DFT Bader charge analysis provided the required insight, being complementary to the XAS data on Fe charge state.

\section{Conclusions}

The present work reports operando characterization of the novel sodium-iron-titanatebased $\mathrm{Na}$-ion cathode material $\mathrm{Na}_{0.9} \mathrm{Fe}_{0.45} \mathrm{Ti}_{1.55} \mathrm{O}_{4}$. The material was studied during cycling as a cathode in Li-ion half-cell by means of Fe K-edge operando X-ray absorption spectroscopy. Two-hundred spectra obtained over $85 \mathrm{~h}$ of electrochemical cycling demonstrate reversible redox reaction and local atomic structure changes for $\mathrm{Fe}$ sites during the first 10 cycles. PCA of these data enabled quantitative analysis of the $\mathrm{Fe}^{2+} / \mathrm{Fe}^{3+}$ ratio at each point of the electrochemical process. Both the specific capacity and conversion rate decreased slightly from the first to the fourth cycle and then remained constant. A possible reason for this behavior is the electrochemical substitution of $\mathrm{Na}$ by Li in the channels of the cathode material and associated with partial blocking of the ionic shuttle. We determined that the number of electrons transferred during discharge was $20 \%$ greater than the number of $\mathrm{Fe}^{2+} / \mathrm{Fe}^{3+}$ transitions derived from PCA of XANES data. Therefore, about $20 \%$ of reversible capacity originated from redox reaction other than $\mathrm{Fe}^{2+} / \mathrm{Fe}^{3+}$ transition. DFT calculations and Bader analysis predict the anionic redox process associated with oxygen atoms in the lattice, which accompanies iron charge changes and dominates at high voltages when $x<0.45$ in $\mathrm{Na}_{x} \mathrm{Fe}_{0.45} \mathrm{Ti}_{1.55} \mathrm{O}_{4}$.

Our work opens new perspectives for the high-throughput screening of novel cathode materials. We demonstrated that laboratory-level equipment can be applied in operando conditions to monitor the charge state of $3 \mathrm{~d}$ metal ions upon cycling. Quantitative analysis of the spectroscopy data powered by principal component analysis provides the fraction of $3 \mathrm{~d}$ metals that undergo redox reaction. This quantity is further compared to the number of electrons transferred through the cell and the electrochemically active phase is verified. Experimental data are used as a benchmark for DFT calculations. When the theoretical model reproduces the observed quantities, it can be extended to a range of parameters 
not accessible by the experimental setup. In this way, we studied the performance of the $\mathrm{Na}_{\mathrm{x}} \mathrm{Fe}_{0.45} \mathrm{Ti}_{1.55} \mathrm{O}_{4}$ material in the whole range of sodium stoichiometry $\mathrm{x}=0 \ldots 1$.

Supplementary Materials: The following are available online at https:/ / www.mdpi.com/2079-499 1/11/1/156/s1, Figure S1: (a) Cell installed into the Rigaku R-XAS Looper laboratory spectrometer and connected to galvanostat. (b) Rigaku R-XAS Looper laboratory spectrometer with additional equipment for operando experiment in front. Figure S2: The first 10 charge-discharge cycles for $\mathrm{Na}_{0.9} \mathrm{Fe}_{0.45} \mathrm{Ti}_{1.55} \mathrm{O}_{4}$ sample cycled in Li-ion half-cell in the 1.6 to $4.5 \mathrm{~V}$ range with a current of $\mathrm{C} / 20 \mathrm{~mA}$ (where $\mathrm{C}$ is the theoretical cell capacity). Figure S3: Experimental Fe K-XANES spectrum for as-prepared $\mathrm{Na}_{0.9} \mathrm{Fe}_{0.45} \mathrm{Ti}_{1.55} \mathrm{O}_{4}$ sample compared to the spectra of $\mathrm{Fe}^{2+}\left(\mathrm{FeTiO}_{3}\right)$ and $\mathrm{Fe}^{3+}(\mathrm{Ox}-$ $\left.\mathrm{Na}_{0.9} \mathrm{Fe}_{0.45} \mathrm{Ti}_{1.55} \mathrm{O}_{4}\right)$ references and its reconstruction with components extracted from PCA. Table S1: Raw Bader charge values obtained from DFT calculations for $\mathrm{M}_{\mathrm{x}} \mathrm{Fe}_{0.45} \mathrm{Ti}_{1.55} \mathrm{O}_{4}$.

Author Contributions: Conceptualization, V.S., A.G., V.B., and I.S.; Data curation, V.S.; Formal analysis, V.S.; Funding acquisition, A.S.; Investigation, V.S.; Methodology, V.S. and A.G.; Project administration, A.S.; Resources, V.B. and I.S.; Supervision, A.S.; Validation, A.G.; Visualization, V.S.; Writing—original draft, V.S.; Writing—review and editing, V.S and A.G. All authors have read and agreed to the published version of the manuscript.

Funding: The work was financially supported by the Ministry of Science and Higher Education of the Russian Federation (State assignment in the field of scientific activity, № 0852-2020-0019).

Institutional Review Board Statement: Not applicable.

Informed Consent Statement: Not applicable.

Data Availability Statement: The data presented in this study are available on request from the corresponding author. This data is not publicly available due to excessive size and complexity of structuring.

Conflicts of Interest: The authors declare no conflict of interest. The funders had no role in the design of the study; in the collection, analyses, or interpretation of data; in the writing of the manuscript; or in the decision to publish the results.

\section{References}

1. Nadeem, F.; Hussain, S.M.S.; Tiwari, P.K.; Goswami, A.K.; Ustun, T.S. Comparative Review of Energy Storage Systems, Their Roles, and Impacts on Future Power Systems. IEEE Access 2019, 7, 4555-4585. [CrossRef]

2. Yuan, Y.; Lu, J. Demanding energy from carbon. Carbon Energy 2019, 1, 8-12. [CrossRef]

3. Cano, Z.P.; Banham, D.; Ye, S.; Hintennach, A.; Lu, J.; Fowler, M.; Chen, Z. Batteries and fuel cells for emerging electric vehicle markets. Nat. Energy 2018, 3, 279. [CrossRef]

4. Yuan, X.; Ma, F.; Zuo, L.; Wang, J.; Yu, N.; Chen, Y.; Zhu, Y.; Huang, Q.; Holze, R.; Wu, Y.; et al. Latest Advances in High-Voltage and High-Energy-Density Aqueous Rechargeable Batteries. Electrochem. Energy Rev. 2020, 1-34. [CrossRef]

5. Biemolt, J.; Jungbacker, P.; Van Teijlingen, T.; Yan, N.; Rothenberg, G. Beyond Lithium-Based Batteries. Materials 2020, 13 , 425. [CrossRef]

6. Xue, Z.; Qi, X.; Li, L.; Li, W.; Xu, L.; Xie, Y.; Lai, X.; Hu, G.; Peng, Z.; Cao, Y.; et al. Sodium Doping to Enhance Electrochemical Performance of Overlithiated Oxide Cathode Materials for Li-Ion Batteries via Li/Na Ion-Exchange Method. ACS Appl. Mater. Interfaces 2018, 10, 27141-27149. [CrossRef]

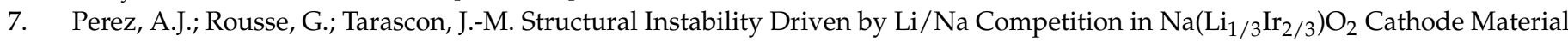
for Li-Ion and Na-Ion Batteries. Inorg. Chem. 2019, 58, 15644-15651. [CrossRef]

8. Gerasimova, L.G.; Nikolaev, A.I.; Shchukina, E.S.; Maslova, M.V. Titanite-Containing Mineral Compositions and Their Chemical Treatment with Preparation of Functional Materials. Materials 2020, 13, 1599. [CrossRef]

9. Voronina, N.; Jo, J.H.; Choi, J.U.; Konarov, A.; Kim, J.; Myung, S.-T. Revealing sodium storage mechanism in lithium titanium phosphate: Combined experimental and theoretical study. J. Power Sources 2020, 455, 227976. [CrossRef]

10. Armand, M.; Tarascon, J.M. Building better batteries. Nature 2008, 451, 652-657. [CrossRef]

11. Goodenough, J.B.; Park, K.-S. The Li-Ion Rechargeable Battery: A Perspective. J. Am. Chem. Soc. 2013, 135, 1167-1176. [CrossRef] [PubMed]

12. Harks, P.P.R.M.L.; Mulder, F.M.; Notten, P.H.L. In situ methods for Li-ion battery research: A review of recent developments. J. Power Sources 2015, 288, 92-105. [CrossRef]

13. Gu, Q.; Kimpton, J.A.; Brand, H.E.A.; Wang, Z.; Chou, S. Solving Key Challenges in Battery Research Using In Situ Synchrotron and Neutron Techniques. Adv. Energy Mater. 2017, 7, 1602831. [CrossRef] 
14. Li, X.; Wang, H.-Y.; Yang, H.; Cai, W.; Liu, S.; Liu, B. In Situ/Operando Characterization Techniques to Probe the Electrochemical Reactions for Energy Conversion. Small Methods 2018, 2, 1700395. [CrossRef]

15. Chen, S.; Wu, C.; Shen, L.; Zhu, C.; Huang, Y.; Xi, K.; Maier, J.; Yu, Y. Challenges and Perspectives for NASICON-Type Electrode Materials for Advanced Sodium-Ion Batteries. Adv. Mater. 2017, 29, 29. [CrossRef]

16. Wang, Q.; Xu, J.; Zhang, W.; Mao, M.; Wei, Z.; Wang, L.; Cui, C.; Zhu, Y.; Ma, J. Research progress on vanadium-based cathode materials for sodium ion batteries. J. Mater. Chem. A 2018, 6, 8815-8838. [CrossRef]

17. Broux, T.; Bamine, T.; Simonelli, L.; Stievano, L.; Fauth, F.; Ménétrier, M.; Carlier, D.; Masquelier, C.; Croguennec, L. VIVDisproportionation Upon Sodium Extraction From $\mathrm{Na}_{3} \mathrm{~V}_{2}\left(\mathrm{PO}_{4}\right)_{2} \mathrm{~F}_{3}$ Observed by Operando X-ray Absorption Spectroscopy and Solid-State NMR. J. Phys. Chem. C 2017, 121, 4103-4111. [CrossRef]

18. Liu, R.; Xu, G.; Li, Q.; Zheng, S.; Zheng, G.; Gong, Z.; Li, Y.; Kruskop, E.; Fu, R.; Chen, Z.; et al. Exploring Highly Reversible 1.5-Electron Reactions $\left(\mathrm{V}^{3+} / \mathrm{V}^{4+} / \mathrm{V}^{5+}\right)$ in $\mathrm{Na}_{3} \mathrm{VCr}\left(\mathrm{PO}_{4}\right)_{3}$ Cathode for Sodium-Ion Batteries. ACS Appl. Mater. Interfaces 2017, 9 , 43632-43639. [CrossRef]

19. Liu, R.; Liang, Z.; Xiang, Y.; Zhao, W.; Liu, H.; Chen, Y.; An, K.; Yang, Y. Recognition of $\mathrm{V}^{3+} / \mathrm{V}^{4+} / \mathrm{V}^{5+}$ Multielectron Reactions in $\mathrm{Na}_{3} \mathrm{~V}\left(\mathrm{PO}_{4}\right)_{2}$ : A Potential High Energy Density Cathode for Sodium-Ion Batteries. Molecules 2020, 25, 1000. [CrossRef]

20. Wang, L.; Wang, J.; Zhang, X.; Ren, Y.; Zuo, P.; Yin, G.; Wang, J. Unravelling the origin of irreversible capacity loss in $\mathrm{NaNiO}_{2}$ for high voltage sodium ion batteries. Nano Energy 2017, 34, 215-223. [CrossRef]

21. Zhang, J.; Zhao, X.; Song, Y.; Li, Q.; Liu, Y.; Chen, J.; Xing, X. Understanding the superior sodium-ion storage in a novel $\mathrm{Na}_{3.5} \mathrm{Mn}_{0.5} \mathrm{~V}_{1.5}\left(\mathrm{PO}_{4}\right)_{3}$ cathode. Energy Storage Mater. 2019, 23, 25-34. [CrossRef]

22. Wang, D.; Bie, X.; Fu, Q.; Dixon, D.; Bramnik, N.; Hu, Y.S.; Fauth, F.; Wei, Y.; Ehrenberg, H.; Chen, G.; et al. Sodium vanadium titanium phosphate electrode for symmetric sodium-ion batteries with high power and long lifespan. Nat. Commun. 2017, 8, 15888. [CrossRef] [PubMed]

23. Shapovalov, V.V.; Guda, A.A.; Kosova, N.V.; Kubrin, S.P.; Podgornova, O.A.; Aboraia, A.M.; Lamberti, C.; Soldatov, A.V. Laboratory operando Fe and Mn K-edges XANES and Mössbauer studies of the $\mathrm{LiFe}_{0.5} \mathrm{Mn}_{0.5} \mathrm{PO}_{4}$ cathode material. Radiat. Phys. Chem. 2020, 175, 108065. [CrossRef]

24. Shukaev, I.L.; Butova, V.V.; Chernenko, S.V.; Pospelov, A.A.; Shapovalov, V.V.; Guda, A.A.; Aboraia, A.M.; Zahran, H.Y.; Yahia, I.S.; Soldatov, A.V. New orthorhombic sodium iron(+2) titanate. Ceram. Int. 2020, 46, 4416-4422. [CrossRef]

25. Petříček, V.; Dušek, M.; Palatinus, L. Crystallographic Computing System JANA2006: General features. Z. Krist. Cryst. Mater. 2014, 229, 345-352. [CrossRef]

26. Ravel, B.; Newville, M. ATHENA, ARTEMIS, HEPHAESTUS: Data analysis for X-ray absorption spectroscopy using IFEFFIT. J. Synchrotron Radiat. 2005, 12, 537-541. [CrossRef]

27. Martini, A.; Guda, S.A.; Guda, A.A.; Smolentsev, G.; Algasov, A.; Usoltsev, O.; Soldatov, M.A.; Bugaev, A.; Rusalev, Y.; Lamberti, C.; et al. PyFitit: The software for quantitative analysis of XANES spectra using machine-learning algorithms. Comput. Phys. Commun. 2020, 250, 107064. [CrossRef]

28. Smolentsev, G.; Soldatov, A.V. FitIt: New software to extract structural information on the basis of XANES fitting. Comput. Mater. Sci. 2007, 39, 569-574. [CrossRef]

29. Klementiev, K.; Chernikov, R. XAFSmass: A program for calculating the optimal mass of XAFS samples. J. Phys. Conf. Ser. 2016, 712, 12008. [CrossRef]

30. Kresse, G.; Furthmüller, J. Efficient iterative schemes forab initiototal-energy calculations using a plane-wave basis set. Phys. Rev. B 1996, 54, 11169-11186. [CrossRef]

31. Kresse, G.; Joubert, D. From ultrasoft pseudopotentials to the projector augmented-wave method. Phys. Rev. B 1999, 59, 1758-1775. [CrossRef]

32. Henkelman, G.; Arnaldsson, A.; Jónsson, H. A fast and robust algorithm for Bader decomposition of charge density. Comput. Mater. Sci. 2006, 36, 354-360. [CrossRef]

33. Tang, W.; Sanville, E.; Henkelman, G. A grid-based Bader analysis algorithm without lattice bias. J. Phys. Condens. Matter 2009, 21, 084204. [CrossRef] [PubMed]

34. Li, M.; Bi, X.; Amine, K.; Lu, J. Oxygen-Based Anion Redox for Lithium Batteries. Acc. Chem. Res. 2020, 53, 1436-1444. [CrossRef] [PubMed]

35. Perez, A.J.; Jacquet, Q.; Batuk, D.; Iadecola, A.; Saubanère, M.; Rousse, G.; Larcher, D.; Vezin, H.; Doublet, M.-L.; Tarascon, J.M. Approaching the limits of cationic and anionic electrochemical activity with the Li-rich layered rocksalt $\mathrm{Li}_{3} \mathrm{IrO}_{4}$. Nat. Energy 2017, 2, 954-962. [CrossRef]

36. Hu, E.; Yu, X.; Lin, R.; Bi, X.; Lu, J.; Bak, S.; Nam, K.-W.; Xin, H.L.; Jaye, C.; Fischer, D.A.; et al. Evolution of redox couples in Li- and Mn-rich cathode materials and mitigation of voltage fade by reducing oxygen release. Nat. Energy 2018, 3, 690-698. [CrossRef]

37. McCalla, E.; Sougrati, M.T.; Rousse, G.; Berg, E.J.; Abakumov, A.; Recham, N.; Ramesha, K.; Sathiya, M.; Dominko, R.; Van Tendeloo, G.; et al. Understanding the Roles of Anionic Redox and Oxygen Release during Electrochemical Cycling of LithiumRich Layered $\mathrm{Li}_{4} \mathrm{FeSbO}_{6}$. J. Am. Chem. Soc. 2015, 137, 4804-4814. [CrossRef]

38. Ishiguro, T.; Tanaka, K.; Marumo, F.; Ismail, M.; Hirano, S.; Somiya, S. Freudenbergite. Acta Crystallogr. Sect. B Struct. Commun. 1978, 34, 255-256. [CrossRef] 
39. Rajagopalan, R.; Chen, B.; Zhang, Z.C.; Wu, X.L.; Du, Y.H.; Huang, Y.; Li, B.; Zong, Y.; Wang, J.; Nam, G.-H.; et al. Improved Reversibility of $\mathrm{Fe} 3+/ \mathrm{Fe} 4+$ Redox Couple in Sodium Super Ion Conductor Type $\mathrm{Na}_{3} \mathrm{Fe}_{2}\left(\mathrm{PO}_{4}\right)_{3}$ for Sodium-Ion Batteries. Adv . Mater. 2017, 29, 1605694. [CrossRef]

40. Seidler, G.T.; Mortensen, D.R.; Remesnik, A.J.; Pacold, J.I.; Ball, N.A.; Barry, N.; Styczinski, M.; Hoidn, O.R. A laboratorybased hard x-ray monochromator for high-resolution x-ray emission spectroscopy and x-ray absorption near edge structure measurements. Rev. Sci. Instrum. 2014, 85, 113906. [CrossRef]

41. Ditter, A.S.; Jahrman, E.P.; Bradshaw, L.R.; Xia, X.; Pauzauskie, P.J.; Seidler, G.T. A mail-in and user facility for X-ray absorption near-edge structure: The CEI-XANES laboratory X-ray spectrometer at the University of Washington. J. Synchrotron Radiat. 2019, 26, 2086-2093. [CrossRef] [PubMed]

42. Jahrman, E.P.; Pellerin, L.A.; Ditter, A.S.; Bradshaw, L.R.; Fister, T.T.; Polzin, B.J.; Trask, S.E.; Dunlop, A.R.; Seidler, G.T. LaboratoryBased X-ray Absorption Spectroscopy on a Working Pouch Cell Battery at Industrially-Relevant Charging Rates. J. Electrochem. Soc. 2019, 166, A2549-A2555. [CrossRef]

43. Yoon, W.-S.; Balasubramanian, M.; Chung, K.Y.; Yang, X.-Q.; McBreen, J.; Grey, C.P.; Fischer, D.A. Investigation of the charge compensation mechanism on the electrochemically Li-ion deintercalated Li1-xCo1/3Ni1/3Mn1/3O2 electrode system by combination of soft and hard X-ray absorption spectroscopy. J. Am. Chem. Soc. 2005, 127, 17479-17487. [CrossRef] [PubMed]

44. Nakanishi, K.; Kato, D.; Arai, H.; Tanida, H.; Mori, T.; Orikasa, Y.; Uchimoto, Y.; Ohta, T.; Ogumi, Z. Novel spectro-electrochemical cell for in situ/operando observation of common composite electrode with liquid electrolyte by X-ray absorption spectroscopy in the tender X-ray region. Rev. Sci. Instrum. 2014, 85, 084103. [CrossRef]

45. Wu, J.; Shen, Z.-X.; Yang, W. Redox Mechanism in Na-Ion Battery Cathodes Probed by Advanced Soft X-Ray Spectroscopy. Front. Chem. 2020, 8, 816. [CrossRef]

46. Saubanère, M.; Yahia, M.B.; Lebègue, S.; Doublet, M.L. An intuitive and efficient method for cell voltage prediction of lithium and sodium-ion batteries. Nat. Commun. 2014, 5, 5559. [CrossRef] 